\title{
Prediction of the chemical composition of lamb carcasses from multi-frequency impedance data
}

\author{
R. S. Hegarty ${ }^{1 *}$, M. J. McPhee ${ }^{2}$, V. H. Oddy ${ }^{3}$, B. J. Thomas ${ }^{4}$ and L. C. Ward ${ }^{5}$ \\ ${ }^{1}$ Elizabeth Macarthur Agricultural Institute, Camden, NSW 2570, Australia \\ ${ }^{2}$ NSW Agriculture Beef Centre, University of New England, Armidale, NSW 2351, Australia \\ ${ }^{3}$ Cattle and Beef Industries Cooperative Research Centre, University of New England, Armidale, NSW 2351, Australia \\ ${ }^{4}$ Centre for Medical and Health Physics, Queensland University of Technology, Brisbane 4001, Australia \\ ${ }^{5}$ Department of Biochemistry, University of Queensland, Brisbane 4072, Australia
}

(Received 17 March 1997 - Revised 3 September 1997 - Accepted 8 September 1997)

\begin{abstract}
Multi-frequency bioimpedance analysis (MFBIA) was used to determine the impedance, reactance and resistance of 103 lamb carcasses $(17 \cdot 1-34.2 \mathrm{~kg})$ immediately after slaughter and evisceration. Carcasses were halved, frozen and one half subsequently homogenized and analysed for water, crude protein and fat content. Three measures of carcass length were obtained. Diagonal length between the electrodes (right side biceps femoris to left side of neck) explained a greater proportion of the variance in water mass than did estimates of spinal length and was selected for use in the index $\mathrm{L}^{2} / \mathrm{Z}$ to predict the mass of chemical components in the carcass. Use of impedance $(Z)$ measured at the characteristic frequency $\left(Z_{c}\right)$ instead of $50 \mathrm{kHz}$ $\left(Z_{50}\right)$ did not improve the power of the model to predict the mass of water, protein or fat in the carcass. While $\mathrm{L}^{2} / \mathrm{Z}_{50}$ explained a significant proportion of variation in the masses of body water $\left(r^{2} 0.64\right)$, protein $\left(r^{2} 0.34\right)$ and fat $\left(r^{2} 0.35\right)$, its inclusion in multi-variate indices offered small or no increases in predictive capacity when hot carcass weight (HCW) and a measure of rib fatdepth (GR) were present in the model. Optimized equations were able to account for $65-90 \%$ of the variance observed in the weight of chemical components in the carcass. It is concluded that single frequency impedance data do not provide better prediction of carcass composition than can be obtained from measures of HCW and GR. Indices of intracellular water mass derived from impedance at zero frequency and the characteristic frequency explained a similar proportion of the variance in carcass protein mass as did the index $L^{2} / Z_{50}$.
\end{abstract}

Carcass composition: Bioelectrical impedance: Lamb

Techniques for simple, non-destructive and repeatable assessment of the absolute fat, protein and ash content of animals have application in both medical and animal science. In medicine, anthropometry or techniques requiring sophisticated, hospital-based equipment are used to gain this information. These techniques have been frequently reviewed and compared (e.g. Richardson et al. 1990; McNeill et al. 1991; Kehayias, 1993). In animal production, the need for mobility has meant marker dilution techniques have been the primary means available (Sainz \& Tulloh, 1990). Recently, bioelectrical impedance analysis developed for estimating body water in human subjects has been evaluated in animals (Berg \& Marchello, 1994; Slanger et al. 1994). In human subjects the accuracy of bioelectrical impedance analysis is comparable with more complex techniques (Richardson et al. 1990; Wilson et al. 1991; Stewart et al. 1993) and has the advantages of being low-cost, portable and less prone to operator error than anthropometry. In animal agriculture it is envisaged that bioelectrical impedance analysis may be useful in assessing the chemical composition of live animals, carcasses and major cuts of meat. A recent enhancement of bioimpedance capabilities is the development of multi-frequency bioimpedance analysis (MFBIA), allowing determination of both

\footnotetext{
Abbreviations: GR, rib fat depth; HCW, hot carcass weight; HWM, hot water mass; MFBIA, multi-frequency bioimpedance analysis.

* Corresponding author: Dr R. S. Hegarty, present address: NSW Agriculture Beef Centre, University of New England, Armidale, NSW 2351, Australia, fax +61267 701830, email rhegarty@metz.une.edu.au
} 
total and extracellular water pools (Cornish et al. 1992; Deurenberg et al. 1995) and calculation of the intracellular water mass by difference.

The present study was undertaken to determine the best combination of length and frequency data for use in biologically based impedance indices to predict the mass of water, protein, fat and fat-free mass in hot lamb carcasses. Impedance indices relating to total body water and intracellular body water were also investigated. In addition the ability of biologically based indices to explain variations in carcass composition was compared with that of equations developed by multiple regressions without a biological basis.

\section{Materials and methods}

\section{Lambs}

Crossbred wether lambs ( $n$ 103) were obtained from a commercial supplier at approximately 3 months of age (29 kg live weight). Dietary treatments imposed were early plane of nutrition (two levels) and the energy density (three levels) and level of protein supplementation (four levels) during finishing. On arrival lambs were allocated into two groups using stratified randomization. One group (low) was fed for slow growth to $35 \mathrm{~kg}$ live weight and the other group (high) was fed on the same diet at $1500 \mathrm{~g} / \mathrm{d}$ (as fed) until the mean live weight of the group was $50 \mathrm{~kg}$. Lambs were then fed ad libitum for a further 10-12 weeks on pelleted rations containing $7.8,9.2$ or $10.7 \mathrm{MJ}$ metabolizable energy/kg DM together with $0,30,60$ or $90 \mathrm{~g} / \mathrm{d}$ formaldehyde-treated casein. Lambs were individually housed for the 34-37 weeks of the experiment then slaughtered (captive bolt and exsanguination) in a private slaughter facility by a trained slaughterman at a rate of sixteen per day. Carcasses and organs were removed and weighed immediately after slaughter and carcasses were reweighed after overnight chilling to determine drip loss.

\section{Impedance}

Immediately after slaughter and dressing, carcasses were hung from a rubber coated (non-conducting) gambrel and one pair of electrodes was pressed into the biceps femoris and the other into the neck while measurements were taken. A tetrapolar MFBIA instrument, model SFB1, and data capture software developed by UniQuest-SEAC (Brisbane, Australia) were used to make the measurements. The instrument measured impedance $(\mathrm{Z}, \Omega)$ and phase angle $\left(^{\circ}\right)$ for 378 logarithmically spaced frequencies in the range 1 to $916 \mathrm{kHz}$ at a constant current of $1.5 \mathrm{~mA}$. Sending and receiving electrodes were held $50 \mathrm{~mm}$ apart in a jig with 18-gauge needles being used as contacts penetrating the carcass to a depth of $6 \mathrm{~mm}$. Resistance $(R, \Omega)$ and reactance $(\mathrm{X}, \Omega)$ were calculated from the measured impedance and phase angle at each frequency according to the relationship: $\mathrm{Z}^{2}=\mathrm{R}^{2}+\mathrm{X}^{2}$. Temperature was determined by stab-thermometers inserted into the hind leg and the shoulder which were removed before impedance analysis was conducted. Approximately $2 \mathrm{~min}$ was required to measure each carcass in duplicate. Duplicate data sets were obtained by repeating the signal generation and data collection processes but the electrodes were not removed from the carcass between repeat analyses. The carcass was split through the sternum and was free of kidneys, kidney fat and all offal at the time of measurement.

Measures of carcass length $\left(\mathrm{L}_{\mathrm{a}}, \mathrm{L}_{\mathrm{b}}\right)$ were determined on the hot carcass at the time of impedance analysis (Fig. 1). Due to an oversight, $\mathrm{L}_{\mathrm{c}}$ was not determined at this time and was determined on lamb sides which had been portioned (to three pieces) after overnight chilling, and frozen. The carcass was reconstructed from the three portions and $\mathrm{L}_{c}$ measured. The location for placement of electrodes in the biceps femoris was readily identified as a fat-free circle approximately $30 \mathrm{~mm}$ in diameter. Subcutaneous fat cover was determined by the thickness of tissue over the lateral surface of the 12 th rib $110 \mathrm{~mm}$ from the mid-line of the spine (the GR site).

The impedance of any body is in part dependent on the frequency of the current being passed through it. In seeking to maximize the precision of impedance data for predicting carcass composition it was considered important to establish the optimum frequency for measurement. Regressions were used to correlate carcass impedance and the masses of water, protein and fat in the carcass at $50 \mathrm{kHz}$, the characteristic frequency and $916 \mathrm{kHz}$ (Table 3). Impedance at the characteristic frequency $\left(Z_{c}\right)$ and zero frequency $\left(Z_{0}\right)$ were derived by the software from ColeCole dispersion plots as described by Ackmann \& Seitz (1984). At the characteristic frequency, biological membranes, acting as imperfect capacitors, exhibit maximal reactance $\left(X_{c}\right)$, while at zero frequency impedance equals resistance (Cornish et al. 1992).

While the ratio water: protein is not constant in animal tissue (Searle \& Graham, 1975; Berg \& Butterfield, 1976) it is thought that intracellular water mass is more highly correlated with protein mass than is total body water (Ross

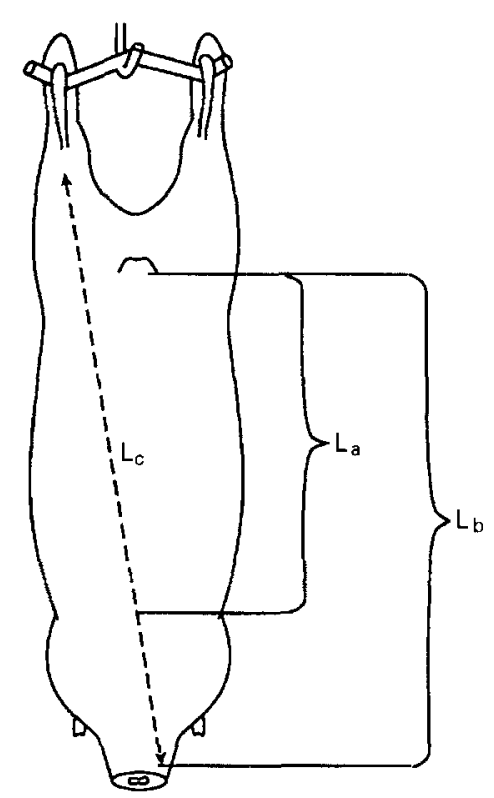

Fig. 1. Measures of carcass length. Measures $L_{a}$ and $L_{b}$ were made on the hot carcass while measure $L_{c}$ was made after the portioned carcass had been trozen. 
et al. 1992) and can be estimated as total body water minus extracellular body water. In the present study extracellular body water was not measured directly but it is known to be very closely correlated with $\mathrm{L}^{2} / \mathrm{Z}_{0}$, because at zero frequency, current is unable to penetrate cell membranes (Cornish et al. 1992). Study was made of the relationship between protein mass and the indicators of intracellular water mass $\left(Z_{c}-Z_{0}\right)$ and $\left(L^{2} / Z_{c}-L^{2} / Z_{0}\right)$.

\section{Carcass analysis}

Frozen half-carcasses were thawed overnight in drip trays then passed through a grinder which chopped the carcass, minced it, and extruded it as a thick paste. The holes in the final grinding plate were $5 \mathrm{~mm}$ in diameter. Half-carcasses were passed through this grinding device twice and the grinder washed and dried between carcasses. Representative subsamples (of approximately $1 \mathrm{~kg}$ ) from each half carcass were kept and frozen for analysis. Approximately $200 \mathrm{~g}$ of this sample was freeze-dried and then homogenized in a high-speed blender before analysis. All chemical analyses were completed in triplicate. Absolute DM content was calculated after oven drying the freezedried material at $105^{\circ}$ until constant weight. Water mass in the hot carcass (HWM) was calculated as water mass of chilled carcass plus overnight drip loss. In most cases, fat content was determined by overnight Soxhlet extraction using chloroform as the solvent and total $\mathrm{N}$ was determined as $\mathrm{NH}_{3}$ after Kjeldahl digestion. Ash was determined by oxidizing (covered) samples at $600^{\circ}$ for $6 \mathrm{~h}$, after a preliminary ashing for $1 \mathrm{~h}$ at $500^{\circ}$. Fat content was able to be accurately predicted as the non-ash, non-protein residue in DM ( $r^{2}$ predicted $v$. measured fat 0.97$)$ so for some samples, fat content of the DM was predicted by this means, not measured by Soxhlet extraction.

\section{Statistical methods}

Single-factor and multi-factor regressions were developed in Genstat 5, Release 3. Stepwise regression was used to develop the optimized multiple regression equations. Presented values for $r^{2}$ and $R^{2}$ are all adjusted coefficients and indicate the proportion of variance attributable to the $x$ variable(s).

\section{Results}

\section{Growth pattern and carcass characteristics}

The nutritional management strategies resulted in a substantial range in weight and composition of carcasses being present at slaughter (Table 1). The range of carcass weights present was normally distributed, as was the water: protein ratio in carcasses across the whole data set, permitting analysis of all data as a single population.

\section{Impedance measurement}

Each impedance profile was screened before use in regressions. Impedance plots were viewed (Fig. 2) and plots with an epicentre above the $\mathrm{x}$ axis ( $n$ 13) were discarded. Duplicate impedance profiles for each lamb were compared and data from a further two lambs were excluded because the duplicate $Z_{50}$ values were not within $5 \%$ of the mean. Chemical analysis was incomplete for four lambs so impedance and carcass composition data were available for a total of eighty-four lambs for use in regression analysis. Electrical properties of the carcasses are summarized in Table 1 .

\section{Length estimates}

Simple comparisons of lengths $\mathrm{L}_{\mathrm{a}}, \mathrm{L}_{\mathrm{b}}, \mathrm{L}_{\mathrm{c}}$ and other indices which may substitute for length were utilized in regressions with the HWM using half of the lambs ( $n 48)$. While the predictive capacity of any measure of carcass length was not great (Table 2), the diagonal length between the two electrodes $\left(L_{c}\right)$ provided the greatest prediction of any length when used alone or in an index utilizing impedance data. For this reason, diagonal length $\mathrm{L}_{c}$ was used in all subsequent evaluations.

There was little effect of signal frequency on the predictive power of the equations used (Table 3), with the mean characteristic frequency being 48 (SD 16.6) $\mathrm{kHz}$. On this basis, further model refinement was conducted utilizing impedance at $50 \mathrm{kHz}$ for the models.

Table 1. Physical and chemical characteristics of crossbred lamb carcasses at completion of a 37week study of nutritional manipulation of growth

(Mean values and standard deviations for 103 carcasses, unless stated otherwise in the text)

\begin{tabular}{lcllrr}
\hline Component masses $(\mathrm{kg})$ & Mean & SD & Carcass attributes & Mean & SD \\
\hline Live wt & 50.5 & 6.0 & ${\text { Length a }(\mathrm{cm})^{\star}}^{*}$ & 55.7 & 2.70 \\
HCW & 24.2 & 3.8 & ${\text { Length b }(\mathrm{cm})^{\star}}^{\star}$ & 74.2 & 3.35 \\
Fat mass & 7.46 & 2.25 & ${\text { Length } \mathrm{c}(\mathrm{cm})^{\star}}^{*}$ & 79.0 & 4.05 \\
Water mass & 12.58 & 1.34 & Temperature $\left.^{\circ}\right)$ & 38.9 & 1.05 \\
Protein mass & 3.51 & 0.46 & $Z_{\mathrm{c}}(\Omega)$ & 175.5 & 13.03 \\
Fat-free mass & 16.75 & 1.86 & $Z_{50}(\Omega)$ & 172.8 & 11.26 \\
Ash mass & 0.75 & 0.17 & $Z_{916}(\Omega)$ & 120.4 & 11.21 \\
GR $(\mathrm{mm})$ & 17.2 & 5.63 & Resistance $(\Omega)$ & 175.5 & 11.15 \\
EMA $\left(\mathrm{cm}^{2}\right)$ & 14.5 & 1.86 & Reactance $(\Omega)$ & 42.0 & 4.91
\end{tabular}

HCW, hot carcass weight; GR, tissue depth over $12 \mathrm{th}$ rib, $110 \mathrm{~mm}$ from spinal midline; EMA, cross-sectional area of the Longissimus dorsi, $Z_{0}, Z_{50}$ and $Z_{918}$, carcass impedance values measured at the characteristic frequency, $50 \mathrm{kHz}$ and $916 \mathrm{kHz}$ respectively.

* Lengths $a, b$ and $c$ are defined in Fig. 1. 


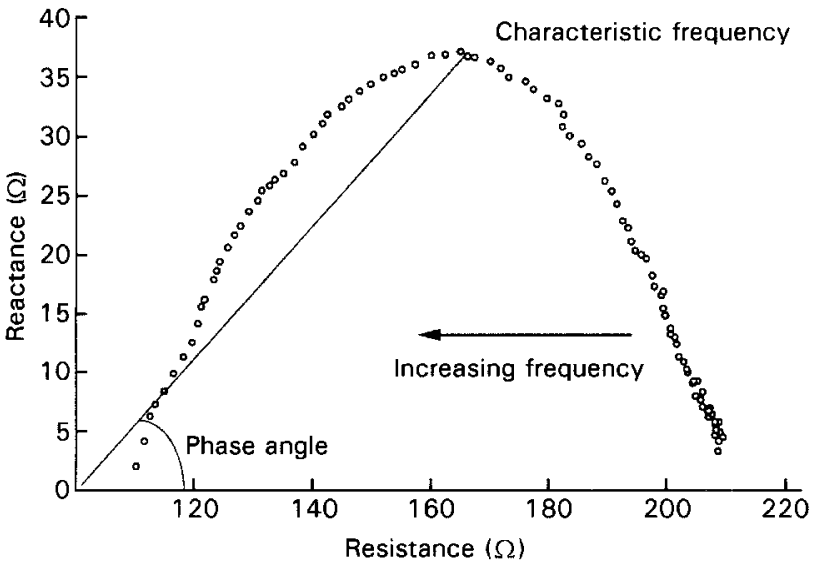

Fig. 2. Cole-Cole dispersion plot of reactance $(X)$ and resistance (R) relationship in a hot lamb carcass. Each point represents the reactance and resistance at a specific frequency. The characteristic frequency is that frequency at which reactance is maximized. Impedance $(Z)$ at any frequency is calculated as $Z=\left(X^{2}+R^{2}\right)^{\frac{1}{2}}$.

Table 2. Correlations between water mass in the hot carcass (HWM) and measures of length alone or in an impedance index

\begin{tabular}{lllc}
\hline Predictor $(x)$ & \multicolumn{1}{c}{ Equation } & $r^{2}$ & SE $(\mathrm{kg})$ \\
\hline $\mathrm{L}_{a}$ & $0.049 x+2.75$ & 0.19 & 1.21 \\
$\mathrm{~L}_{b}$ & $0.259 x-6.6$ & 0.41 & 1.03 \\
$\mathrm{~L}_{c}$ & $0.242 x-6.52$ & 0.51 & 0.95 \\
$\mathrm{~L}_{a}{ }^{2} / Z_{50}$ & $0.35 x+6.24$ & 0.35 & 1.09 \\
$L_{b}{ }^{2} / Z_{50}$ & $0.262 x+4.18$ & 0.56 & 0.89 \\
$L_{c}{ }^{2} / Z_{50}$ & $0.230 x+4.22$ & 0.64 & 0.82
\end{tabular}

$L_{a}, L_{b}, L_{c}$, lengths $a, b$ and $c$ as defined in Fig. $1 ; Z_{50}$, impedance value measured at $50 \mathrm{kHz}$.

\section{Impedance data utilized in a biological model}

Having concluded that the power of impedance data is greatest for predicting body composition when the direct length between electrodes is used and that measurement can be made at $50 \mathrm{kHz}$, tests were made to establish the most appropriate predictive index using impedance data. Early modellers likened the human body to a number of inter-connected cylinders and thus deduced that electrical signals should behave as in a cylinder of water of volume (V); the mathematical product of cross-sectional area
(A) $\times$ length $(\mathrm{L})$. The impedance of such a cylinder is given in equation 1 .

$$
\mathrm{Z} \propto \mathrm{L} / \mathrm{A}
$$

or

$$
\mathrm{Z}=\rho \mathrm{L} / \mathrm{A},
$$

where $\rho$ is the specific resistivity. Rearranging this equation gives:

$$
\mathrm{V}=\rho \mathrm{L}^{2} / \mathrm{Z},
$$

where $\mathrm{V}$ is the conductive volume of body water.

It is reasonable to expect, therefore, that total body water should be accurately described as some function of $\mathrm{L}^{2} / \mathrm{Z}$. This approach has been used in rats (Cornish et al. 1992) as well as human subjects and so was evaluated in the present carcasses. It should be appreciated that carcasses were freshly killed, free of viscera and had been split through the sternum at the time of measurement and, while representative of industry practice, were therefore not ideal for this model.

In addition, extra information on carcass weight and fat cover is normally readily available to animal scientists in research institutes and abattoirs. In seeking to get the most precise predictor, an impedance index $\left(\mathrm{L}^{2} / \mathrm{Z}\right), \mathrm{HCW}$ and GR (tissue depth over the 12 th rib, $110 \mathrm{~mm}$ from the spine) were combined in a stepwise multiple regression analysis (Table 4).

Table 4. Coefficients of determination $\left(R^{2}\right)$ for models predicting the mass of water, protein and fat in the carcass of lambs

\begin{tabular}{|c|c|c|c|c|c|c|}
\hline & \multicolumn{2}{|c|}{$\begin{array}{l}\text { Water mass } \\
(\mathrm{kg})\end{array}$} & \multicolumn{2}{|c|}{$\begin{array}{l}\text { Protein } \\
\text { mass }(\mathrm{kg})\end{array}$} & \multicolumn{2}{|c|}{$\begin{array}{c}\text { Fat mass } \\
(\mathrm{kg})\end{array}$} \\
\hline & $R^{2}$ & SEE & $R^{2}$ & SEE & $R^{2}$ & SEE \\
\hline $\begin{array}{l}\mathrm{HCW} \\
\mathrm{GR} \\
\mathrm{HCW}+\mathrm{GR} \\
\mathrm{L}^{2} / \mathrm{Z}^{*} \\
\mathrm{~L}^{2} / \mathrm{H}+\mathrm{HCW} \\
\mathrm{L}^{2} / Z+\mathrm{GR} \\
\mathrm{L}^{2} / Z+\mathrm{HCW}+\mathrm{GR}\end{array}$ & $\begin{array}{l}0.78 \\
0.28 \\
0.89 \\
0.64 \\
0.83 \\
0.61 \\
0.90\end{array}$ & $\begin{array}{l}0.63 \\
1.03 \\
0.41 \\
0.82 \\
0.57 \\
0.78 \\
0.40\end{array}$ & $\begin{array}{l}0.65 \\
0.36 \\
0.64 \\
0.34 \\
0.66 \\
0.43 \\
0.67\end{array}$ & $\begin{array}{l}0.27 \\
0.35 \\
0.26 \\
0.38 \\
0.27 \\
0.33 \\
0.25\end{array}$ & $\begin{array}{l}0.88 \\
0.74 \\
0.91 \\
0.35 \\
0.89 \\
0.81 \\
0.91\end{array}$ & $\begin{array}{l}0.78 \\
0.85 \\
0.53 \\
1.83 \\
0.74 \\
0.75 \\
0.52\end{array}$ \\
\hline
\end{tabular}

(Coefficients of determination and standard errors of the estimate (kg substance))

HCW, hot carcass weight; GR, tissue depth over 12 th rib, $110 \mathrm{~mm}$ from spinal midline; $L$, length; $Z$, impedance value.

- Length used was diagonal length between electrodes $\left(L_{c}\right)$; impedance was measured at $50 \mathrm{kHz}$.

Table 3. Proportion of variance in water, protein and fat in the carcass of lambs $\left(r^{2}\right)$ explained by a simple impedance index at frequencies of $50 \mathrm{kHz}\left(Z_{50}\right), 916 \mathrm{kHz}\left(Z_{916}\right)$ or the characteristic

\begin{tabular}{|c|c|c|c|c|c|c|c|}
\hline \multirow[b]{3}{*}{ Component } & \multirow[b]{3}{*}{ Index* } & \multicolumn{6}{|c|}{ Frequency for impedance measure } \\
\hline & & \multicolumn{2}{|l|}{$Z_{50}$} & \multicolumn{2}{|l|}{$\mathrm{Z}_{\mathrm{c}}$} & \multicolumn{2}{|l|}{$Z_{916}$} \\
\hline & & Proportion & SE & Proportion & SE & Proportion & SE \\
\hline $\begin{array}{l}\text { Water mass } \\
\text { Protein mass } \\
\text { Fat mass }\end{array}$ & $\begin{array}{l}L^{2} / Z \\
L^{2} / Z \\
L^{2} / Z\end{array}$ & $\begin{array}{l}0.64 \\
0.34 \\
0.35\end{array}$ & $\begin{array}{l}0.82 \\
0.38 \\
1.80\end{array}$ & $\begin{array}{l}0.60 \\
0.30 \\
0.28\end{array}$ & $\begin{array}{l}0.86 \\
0.39 \\
1.90\end{array}$ & $\begin{array}{l}0.57 \\
0.33 \\
0.37\end{array}$ & $\begin{array}{l}0.90 \\
0.38 \\
1.80\end{array}$ \\
\hline
\end{tabular}
frequency $\left(Z_{c}\right)$

(Proportions of variance, and standard errors ( $\mathrm{kg}$ substance))

*Length used was the diagonal length between electrodes $\left(L_{c}\right)$. 
The impedance index $\left(\mathrm{L}^{2} / \mathrm{Z}\right)$ and $\mathrm{GR}$ were excluded from the equation predicting protein mass. Similarly, impedance index did not significantly improve the fat mass prediction but all predictors were included for HWM. The optimized equations follow. Standard error of the estimate (SEE) and the standard error of each component in the equation are provided on the line beneath.

$$
\begin{array}{lccc}
\text { HWM }(\mathrm{kg}) & 0.038 \times \mathrm{L}^{2} / \mathrm{Z}+0.447 \times \mathrm{HCW} \\
\text { SEE } 0.40 & 0.0163 & 0.033 \\
& \multicolumn{4}{c}{0.093 \times \mathrm{GR}+2.189} & r^{2} 0.90 \\
& 0.014 & 0.45 & \\
\text { Protein mass }(\mathrm{kg}) & 0.987 \times \mathrm{HCW}+1.118 & r^{2} 0.65 \\
\text { SEE } 0.27 & 0.079 & 0.194 &
\end{array}
$$

Fat mass $(\mathrm{kg})$

$$
\begin{array}{ccccc} 
& 0.345 \times \mathrm{HCW}+0.107 \times \mathrm{GR}-3.027 & r^{2} 0.90 \\
\text { SEE } 0.53 & 0.032 & 0.018 & 0.55 &
\end{array}
$$

\section{Multiple regression analysis}

In contrast to the many studies which seek to utilize impedance data within a biological (cylinder) model (see Foster \& Lukaski 1996), some animal researchers (Berg \& Marchello, 1994) have put aside underlying biological mechanisms and explored simple correlations between body composition and a host of measures of resistance, reactivity and impedance. Current data were reanalysed in multiple linear regressions in the manner of Berg \& Marchello (1994) to determine the most appropriate empirical model to predict HWM, protein mass and fatfree mass (Table 5).
The most appropriate equations to predict HWM and fatfree mass comprised two variables; $\mathrm{HCW}$ and resistance. The remaining variables length, temperature and reactance were excluded from the model. The model for protein mass also excluded all variables except $\mathrm{HCW}$. Models are shown here with dependent variables. Beneath each equation is given the standard error of the estimate (SEE) in kilograms and standard errors for each component.

\begin{tabular}{lccrr} 
HWM & \multicolumn{2}{l}{$0.281 \times \mathrm{HCW}-0.032 \mathrm{R}+11.04$} & $r^{2} 0.838$ \\
SEE 0.56 & 0.017 & 0.006 & 1.23 & \\
Fat mass & $0.577 \times \mathrm{HCW}+0.031 \mathrm{R}-11.85$ & $r^{2} 0.899$ \\
SEE 0.74 & 0.224 & 0.008 & 1.62 & \\
Fat-free mass & $0.480 \times \mathrm{HCW}-0.012 \mathrm{R}+8.73$ & $r^{2} 0.868$ \\
SEE 0.74 & 0.026 & 0.0075 & 1.64 & \\
Protein mass & $0.0987 \times \mathrm{HCW}+1.128$ & $r^{2} 0.652$ \\
SEE 0.27 & 0.0079 & 0.194 &
\end{tabular}

\section{Correlations with intracellular water mass}

There was little difference between the variance in protein mass explained by the index $\mathrm{L}^{2} / Z_{50}\left(r^{2} 0.34\right)$ and a more complex index (Fig. 3) reflecting the intracellular water mass $\left(\mathrm{L}^{2} / \mathrm{Z}_{\mathrm{c}}-\mathrm{L}^{2} / \mathrm{Z}_{0} ; r^{2} 0.34\right)$. The index $\left(\mathrm{Z}_{\mathrm{c}}-\mathrm{Z}_{\mathrm{o}}\right)$ was very poorly correlated with protein mass $\left(r^{2} 0.01\right)$.

\section{Discussion}

\begin{tabular}{|c|c|c|c|c|c|c|c|c|}
\hline \multirow[b]{2}{*}{ Predictor } & \multicolumn{2}{|c|}{ Fat-free mass } & \multicolumn{2}{|c|}{ Hot water mass } & \multicolumn{2}{|c|}{ Protein mass } & \multicolumn{2}{|c|}{ Fat mass } \\
\hline & $R^{2}$ & SEE & $R^{2}$ & SEE & $R^{2}$ & SEE & $R^{2}$ & SEE \\
\hline $\begin{array}{l}\mathrm{L}(n 80) \\
\mathrm{T}(n 84) \\
\mathrm{X}(n 83) \\
\mathrm{R}(n 83) \\
\mathrm{HCW}(n 84) \\
\mathrm{R}, \mathrm{X} \\
\mathrm{L}, \mathrm{R} \\
\mathrm{HCW}, \mathrm{L} \\
\mathrm{HCW}, \mathrm{R} \\
\mathrm{L}, \mathrm{R}, \mathrm{X} \\
\mathrm{HCW}, \mathrm{R}, \mathrm{T} \\
\mathrm{HCW}, \mathrm{R}, \mathrm{L} \\
\mathrm{HCW}, \mathrm{R}, \mathrm{X} \\
\mathrm{HCW}, \mathrm{L}, \mathrm{R}, \mathrm{T} \\
\mathrm{HCW}, \mathrm{L}, \mathrm{R}, \mathrm{X} \\
\mathrm{HCW}, \mathrm{R}, \mathrm{X}, \mathrm{T} \\
\mathrm{HCW}, \mathrm{L}, \mathrm{R}, \mathrm{X}, \mathrm{T}\end{array}$ & $\begin{array}{l}0.524 \\
0.210 \\
0.036 \\
0.148 \\
0.824 \\
0.186 \\
0.525 \\
0.854 \\
0.868 \\
0.532 \\
0.866 \\
0.867 \\
0.868 \\
0.865 \\
0.866 \\
0.866 \\
0.864\end{array}$ & $\begin{array}{l}1.30 \\
1.84 \\
1.83 \\
1.72 \\
0.78 \\
1.56 \\
1.19 \\
0.66 \\
0.63 \\
1.18 \\
0.63 \\
0.63 \\
0.63 \\
0.64 \\
0.63 \\
0.63 \\
0.64\end{array}$ & $\begin{array}{l}0.514 \\
0.290 \\
0.073 \\
0.200 \\
0.781 \\
0.182 \\
0.637 \\
0.777 \\
0.833 \\
0.638 \\
0.831 \\
0.839 \\
0.833 \\
0.837 \\
0.837 \\
0.831 \\
0.835\end{array}$ & $\begin{array}{l}0.95 \\
1.32 \\
1.29 \\
1.20 \\
0.63 \\
1.24 \\
0.82 \\
0.64 \\
0.56 \\
0.82 \\
0.56 \\
0.55 \\
0.56 \\
0.55 \\
0.55 \\
0.56 \\
0.55\end{array}$ & $\begin{array}{l}0.391 \\
\star \\
\star \\
0.220 \\
0.652 \\
0.015 \\
0.389 \\
0.658 \\
0.659 \\
0.415 \\
0.664 \\
0.654 \\
0.658 \\
0.660 \\
0.654 \\
0.668 \\
0.663\end{array}$ & $\begin{array}{c}0.36 \\
* \\
* \\
0.46 \\
0.27 \\
0.46 \\
0.36 \\
0.27 \\
0.27 \\
0.36 \\
0.27 \\
0.27 \\
0.27 \\
0.27 \\
0.27 \\
0.27 \\
0.27\end{array}$ & $\begin{array}{l}0.481 \\
0.007 \\
\star \\
0.005 \\
0.879 \\
\star \\
0.471 \\
0.878 \\
0.896 \\
0.485 \\
0.895 \\
0.898 \\
0.895 \\
0.896 \\
0.896 \\
0.894 \\
0.895\end{array}$ & $\begin{array}{c}1.64 \\
2.24 \\
\star \\
2.25 \\
0.78 \\
* \\
1.66 \\
0.80 \\
0.74 \\
1.64 \\
0.74 \\
0.73 \\
0.74 \\
0.74 \\
0.74 \\
0.75 \\
0.74\end{array}$ \\
\hline
\end{tabular}

The impedance of an object to the flow of current is determined by the frequency of current, and the size, geometry and intrinsic electrical properties of the object (Foster \& Lukaski, 1996). Traditional indices of body mass

Table 5. Multiple regressions relating the composition of lamb carcasses to their physical characteristics and electrical characteristics measured at $50 \mathrm{kHz}$

(Values are coefficients of determination, and standard errors of the estimate (kg substance))

$L$, length; $T$, carcass temperature; $X$, reactance; $R$, resistance; HCW, hot carcass weight.

* No variance was accounted for when these terms were added. 

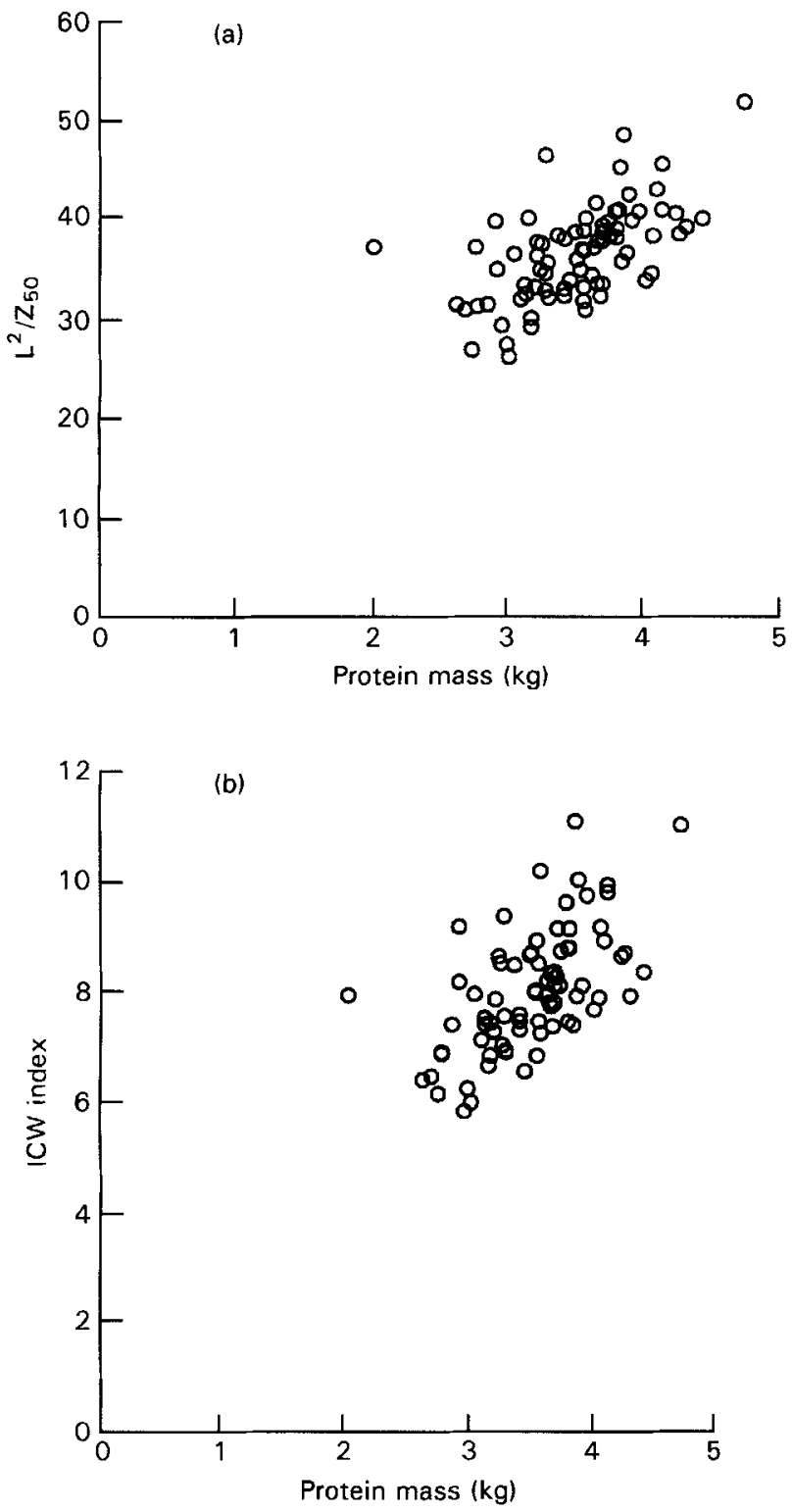

Fig. 3. (a) Relationship between carcass protein mass and an index of total carcass water $\left(\mathrm{L}^{2} / Z_{50}\right.$, where $L$ is length and $Z_{50}$ is impedance at $50 \mathrm{kHz}$ ). Protein $=0.0532 \times\left(L^{2} / Z\right)+1.608$ (SE $\left.0.38, r^{2} 0.34\right)$. (b) Relationship between carcass protein mass and an indexed intracellular water $(I C W)$ mass, where $I C W$ index $=\left(L^{2} / Z_{C}-L^{2} / Z\right)$. Protein $=0.250 \times \mathrm{ICW}$ index +1.157 (SE $0.38, r^{2} 0.34$ ).

or lean body mass (Nevill \& Holder, 1995) developed in clinical studies can be used to account for the contribution of geometrical and size variation to whole body impedance, allowing it to be tightly correlated with total body water (Settle et al. 1980). These same indices have been used in interpreting impedance data from animals (Cornish et al. 1992) but it is important that parameters contributing to such an index are optimized. The present study sought to identify the optimum impedance-based model to predict carcass water, protein and fat by evaluating measures of length, signal frequency and the need to account for geometry.

While in many reports, the estimate of length used in impedance models is unrelated to path-length, the present study found that length between electrodes $\left(\mathrm{L}_{\mathrm{c}}\right)$ explained a greater proportion of variance in HWM than did tail-toneck or tail-to-shoulder measures. There are probably two contributing factors to this. First, large differences in HCW existed between carcasses with similar spinal lengths $\left(L_{a}\right.$, $\mathrm{L}_{\mathrm{b}}$ ). In contrast, the range $\mathrm{L}_{\mathrm{c}}$ was greater and was more closely related to HCW $\left(r^{2} 0.56 v . r^{2} 0.20\right.$ for $\mathrm{L}_{\mathrm{a}}$ and $r^{2} 0.35$ for $L_{b}$ ) Second, by positioning the rear electrodes in the hind leg, a greater proportion of the carcass was contained between the current and measurement electrodes and this may have improved the accuracy of determining the whole carcass impedance. Additionally location of electrode sites on the biceps femoris and neck used for $L_{\mathfrak{c}}$ were easily defined for accurate placement. Shoulder and neck sites required for determining $L_{a}$ and $L_{b}$ were, however, difficult to locate with confidence.

In contrast, Berg \& Marchello (1994) recommend dorsally-placed electrodes and measures of spinal length; Cosgrove et al. (1988) used electrodes placed on the extremities with a measure of the length of the body cavity (first rib to hip). The evaluation in the present study suggests that diagonal placement of electrodes on the neck and hind leg and use of direct path-length for $\mathrm{L}$ should be adopted.

While the $\mathrm{L}^{2} / \mathrm{Z}$ model based on cylinder volume has been widely used, it is perhaps an inaccurate reflection of carcass geometry and there was little difference in the predictive capacity of optimized indices based on the cylinder $\left(\mathrm{L}^{2} / \mathrm{Z}\right)$ approach compared with the simple empirical multiple regressions. While path-length (a measure of size) is known to have a fundamental bearing on impedance, this parameter was able to be excluded from the empirical models of Berg \& Marchello (1994) in their own studies and also in the present study without loss of predictive capability. From both the mechanistic and empirical approaches it was apparent that the greatest contribution in all predictions was made by HCW and that this is a superior indicator of tissue mass than is length.

The index $\mathrm{L}^{2} / \mathrm{Z}$ alone was less effective in predicting HWM than was HCW alone (Table 4). Combining these two predictors slightly increased the predictive power for most carcass constituents but the increase $(1 \cdot 1-6.4 \%)$ is unlikely to justify making the measurement of impedance in addition to carcass weight. Where rib-fat depth data were not available, Berg \& Marchello (1994) were able to improve the proportion of fat-free mass accounted for from 0.56 to 0.72 by incorporating resistance data with $\mathrm{HCW}$, but where fat depth or eye muscle area data are available, the benefit of including any electrical data is very small (Jenkins et al. 1988). Similarly, prediction of dissectible meat or retail yield of meat is not enhanced by inclusion of impedance measures over carcass weight and rib fat depth (Slanger et al. 1994; Hopkins \& Hegarty, 1995).

In human studies impedance is finding favour because of its convenience but comparative studies have found it no more accurate in predicting body water mass of normal individuals than conventional means of skinfold thickness, tritiated or deuterated water, X-ray absorption, densitometry or body K (Richardson et al. 1990; McNeill et al. 1991; De Waart et al. 1993; Stewart et al. 1993). Dispute over the need for separate calibrations for human subjects 
from differing ethnic groups (De Waart et al. 1993) and for the sexes (Richardson et al. 1990; Stewart et al. 1993) suggests variation due to sex and genotype may also need to be considered in calibrations for livestock.

The present study gives no evidence that impedance measured at the characteristic frequency is of advantage relative to impedance measured at $50 \mathrm{kHz}$ when a single frequency model is used. Indices predicting intracellular water, however, require that MFBIA be used. In impedance theory the body may be likened to a circuit of capacitors (cell membranes) and resistors (intracellular and extracellular fluids). At low frequency, current is unable to pass through the capacitor (membrane and intracellular water) so the impedance observed is attributable only to the extracellular fluid. Recently the appropriateness of this theory to elongated muscle cells rather than 'ideal' spherical cells has been questioned (Foster \& Lukaski, 1996) but excellent correlations between $L^{2} / Z$ and extracellular water have been achieved (Cornish et al. 1992). The fact that our results show protein mass in freshly killed and dressed lamb carcasses was no better correlated with an intracellular water index $\left(\mathrm{L}^{2} / \mathrm{Z}_{\mathrm{c}}-\mathrm{L}^{2} / \mathrm{Z}_{\mathrm{o}}\right)$ than a total body water index $\left(\mathrm{L}^{2} / \mathrm{Z}_{50}\right)$ may be attributable to several factors. These may include the very small extracellular fluid space in carcasses after bleeding and evisceration and a rapid change in the electrical properties of tissue after slaughter as has been found with ischaemia (Löfgren, 1951).

In human medicine the application of MFBIA appears to be in assessing individuals with abnormal body composition due to a health disorder rather than normal healthy individuals (e.g. Holt et al. 1994). In animal science it is likely that single frequency impedance measurements (be they at $50 \mathrm{kHz}$ or the characteristic frequency) will be most appropriately used in grading animals or carcasses for their commercial usefulness (e.g. Slanger et al. 1994) rather than providing accurate analysis on specific individuals. This means that fixed frequency impedance measurement, while cheap, simple and fast, is unlikely to be used to identify superior individuals in genetic selection programmes. Further investigation of appropriate models using multi-frequency data based on different principles of geometry is required to further develop the accuracy of bioimpedance as a tool for assessing carcass composition.

\section{Acknowledgements}

The assistance of Robyn Smith, Kristine Riley, Helena Warren, Kuldip Nandra, Arthur Jones and Allan Hendry in making impedance measurements and conducting the slaughter of animals is acknowledged. The tireless work of Robyn Smith and Allan Hendry in completing the chemical analysis of carcasses is also gratefully acknowledged. This study was partly funded by the Meat Research Corporation, Australia.

\section{References}

Ackmann JA \& Seitz MA (1984) Methods of complex impedance measurements in biological tissue. CRC Critical Reviews in Biomedical Engineering 11, 281-311.
Berg EP \& Marchello MJ (1994) Bioelectrical impedance analysis for the prediction of fat-free mass in lambs and lamb carcasses. Journal of Animal Science 72, 322-329.

Berg RT \& Butterfield RM (1976) New Concepts of Cattle Growth. Sydney: Sydney University Press.

Cornish BH, Ward LC \& Thomas BJ (1992) Measurement of extracellular and total body water of rats using multiple frequency bioelectrical impedance analysis. Nutrition Research 12, 657-666.

Cosgrove JR, King JWB \& Brodie DA (1988) A note on the use of impedance measurements for the prediction of carcass composition in lambs. Animal Production 47, 311-315.

Deurenberg P, Tagliabue A \& Schouten FJM (1995) Multifrequency impedance for the prediction of extracellular water and total body water. British Journal of Nutrition 73, 349-358.

De Waart FG, Li R \& Deurenberg P (1993) Comparison of body composition assessments by bioelectrical impedance and by anthropometry in premenopausal Chinese women. British Journal of Nutrition 69, 657-664.

Foster KR \& Lukaski HC (1996) Whole-body impedance - what does it measure? American Journal of Clinical Nutrition 64, Suppl., 388s-396s.

Holt TL, Cui C, Thomas BJ, Ward LC, Quirk PC, Crawford D \& Shepherd RW (1994) Evaluation of bioelectric impedance as a measure of body composition in children and adults in health and disease. Nutrition 10, 221-224.

Hopkins DL \& Hegarty RS (1995) Relationship between bioimpedance and muscle mass in chilled lamb carcasses. Proceedings of the New Zealand Society of Animal Production 55, 117-119.

Jenkins TG, Leymaster KA \& Turlington LM (1988) Estimation of fat-free soft tissue in lamb carcasses and resistive impedance measurements. Journal of Animal Science 66, 2174-2179.

Kehayias JJ (1993) Aging and body composition: possibilities for future studies. Journal of Nutrition 123, 454-458.

Löfgren B (1951). The electrical impedance of a complex tissue and its relation to changes in volume and fluid distribution: study on rat kidneys. Acta Physiologica Scandinavica 23, Suppl. 81, $1-51$.

McNeill GM, Fowler PA, Maughan RJ, McGaw BA, Fuller MF, Gvozdanovic D \& Gvozdanovic S (1991) Body fat in lean and overweight women estimated by six methods. British Journal of Nutrition 65, 95-103.

Nevill AM \& Holder RG (1995) Body mass index: a measure of fatness or leanness? British Journal of Nutrition 73, 507-516.

Richardson RA, Fearon KCH, Watson W, Hume R \& Shenkin A (1990) Assessment of body composition by bioelectrical impedance compared with anthropometry, total body potassium and tritiated water dilution. Proceedings of the Nutrition Society 49, 195A.

Ross JG, Preston RL \& Bartle SJ (1992) Evaluation of sodium thiosulphate as an extracellular water marker in cattle. Journal of Animal Science 70, 434-438.

Sainz RD \& Tulloh NM (1990) Measurement of body composition in farm animals: research and practical applications. Proceedings of the Nutrition Society of Australia 15, 196-201.

Searle TW \& Graham NMcC (1975) Studies of weaner sheep during and after a period of weight stasis. II. Body composition. Australian Journal of Agricultural Research 26, 355-361.

Settle RG, Foster KR, Epstein BR \& Mullen JL (1980) Nutritional assessment: whole-body impedance and body fluid compartments. Nutrition and Cancer 2, 72-80.

Slanger WD, Marchello MJ, Busboom JR, Meyer HH, Mitchell LA, Hendrix WF, Mills RR \& Warnock WD (1994) Predicting total weight of retail-ready lamb cuts from bioelectrical impedance measurements taken at the processing plant. Joumal of Animal Science 72, 1467-1474. 
Stewart SP, Bramley PN, Heighton R, Green JH, Horsman A, Losowsky MS \& Smith MA (1993) Estimation of body composition from bioelectrical impedance of body segments: comparison with dual-energy X-ray absorptiometry. British Journal of Nutrition 69, 645-655.
Wilson DC, Baird T, Scrimgeour CM, McClure G, Halliday HL, Reid MMcC \& Rennie MJ (1991) Total body water measurement in very low birth weight infants using bioelectrical impedance. Proceedings of the Nutrition Society 51, 39A. 